\title{
An Empirical Study of the Hindrance Factors of E-commerce Development in Small and Medium Enterprises
}

\author{
Hongda $\mathrm{Lu}$ \\ Management School of Shenzhen Polytechnic \\ Shenzhen, China \\ luhongda@szpt.edu.cn
}

\begin{abstract}
This article summarizes and reviews some Chinese and international factors that hinder the e-commerce development of Chinese small and medium enterprises (SMEs) based on an empirical research from a new perspective. This study shows that the hindrance factors are multi-fold, and that the hindrance force exhibits differences between different hindrance factors and also between different stages. Leader factor is obviously significant in the early stage of e-commerce development. But in its development stage, informatization level and e-commerce application level play a critical role. Technical factors and the conditions of the industry are closely connected as different kinds of enterprises have different demands in technology in their process to develop e-commerce. What's more, background factors such as human resources have been always playing important roles in developing e-commerce in SMEs.
\end{abstract}

Keywords-- small-and-median enterprises; -commerce development; indrance factors; ackground factors

\section{INTRODUCTION}

The emergence of e-commerce has made those enterprises that are in urgent need to enhance their competitiveness join the e-commerce world. After experiencing the "Internet Bubble" around 2000, some researchers and enterprises nowadays again consider e-commerce as their magic weapon to win in the competition. Statistics shows that $69.1 \%$ Chinese enterprises built their own websites, $21.6 \%$ developed e-commerce business, $4.1 \%$ did their procurement from Internet, and $3.4 \%$ carried out their marketing business on the Internet[1]. Some SMEs are confounded because when they invested their labor, properties and money to try to enhance their e-commerce performances, only a few percent of them made profits from e-commerce, some of them even lost money in those investments. In a word, many SMEs' investments did not bring their expected profits or even reduced profits. Therefore, the academia and the industry are concerned with some basic questions: theoretically, e-commerce can reduce costs, expand markets and make profits, but why is it so hard to make these benefits into reality? What are the factors that hinder the application of e-commerce? What are the critical hindrance factors, and how critical are they? This article tries to answer these questions.

\section{LITERATURE REVIEW}

As a new development model for enterprises, e-commerce has been continuously explored by both domestic Chinese and foreign researchers. Researches on the hindrance factors of e-commerce in SMEs were mainly done on a micro level. Foreign researches are focused on success factors while domestic Chinese researches are focused on hindrance factors.

Recently, the practice and research of e-commerce has been a hot issue in foreign countries. However, generally speaking, there is no systematic study in the field. Main studies include: Kang's business value model of successful e-commerce, which indicates that technical integration and organizational change are critical success factors; Sung (2006) studied about the critical success factors of e-commerce. He concluded that there are 16 critical success factors: customer-orientation, privacy, low-cost, strategy, experts, ease-to-use, stability, richness, diversity, safety, speed, service, payment, low-price, shipping, and comments[2]. These literature reviews found that researchers not only pointed out there existed problems of too many successful factors, but also identified the most important successful factors that influence the success of e-commerce[3] .

Although a great number of researches on the hindrance factors of e-commerce have been done by domestic researchers, they are mainly qualitative studies. They started with success factors of e-commerce application; however, the data they used in the researches are from those enterprises that have not fully achieved their success yet, which only lead to inaccurate conclusions. From a new and different perspective, this article starts from the hindrance factors of e-commerce of SMEs and studies the correlation of two different kinds of factors, which hopefully can make contributions to the practice of e-commerce for SMEs[4] .

The domestic Chinese researches on hindrance factors of e-commerce are mainly focused on hindrance factors and success factors.

The hindrance factors include: outdated opinions, lack of business environment for e-commerce, incomplete internet infrastructure, low-quality internet, internet insecurity, lack of e-commerce talents and knowledge, insufficient investment, and incomplete 
regulations and laws [5] .

The success factors are: clear strategy and target market, innovation ability to use the Internet, investment and persistence in Internet, rich human resources pool, integration and distribution of resources and information, and integration with traditional industries [6].

From the Chinese domestic researches on the hindrance factors of e-commerce in enterprises, it is not difficult to find that they are focused on both success and hindrance factors, most of which are empirical studies of enterprises or industries. These researches have provided useful reference to this article, especially their analysis and empirical studies on different factors. Although they appear as success factors for e-commerce enterprises, they can be at the same time the obstacle factors for SMEs.

Relating these studies to Internet economy, we find that there are several demerits in these studies: first, foreign researches mainly focused on success factors, listing factors for the success of e-commerce enterprises. In other words, it is feasible for other SMEs to develop their e-commerce in the same way. But in fact, since e-commerce enterprises are mostly oligopoly, there are not many enterprises which can copy these success factors and win. As a result, the success factors cannot be copied in a general sense. Even if they can be copied, they will not bring about the expected success due to different environments that different enterprises are in. Second, the list of success factors is not inclusive. There are many "hygiene" factors that cannot be copied. Even if an enterprise successfully copies all the factors of a successful e-commerce enterprise, it will not necessarily succeed. Hence, researches that are done purely on success factors will not be a valuable guidance for the development of e-commerce enterprises.

Domestic Chinese researches are done on both successful factors and hindrance factors. In the study of hindrance factors, domestic Chinese researches are mainly focused on macro environmental obstacles faced by SMEs. In fact, most enterprises face the same or similar macro environment. It is meaningless if we attribute the e-commerce development of a single enterprise entirely to the external environment. The e-commerce development of an enterprise critically depends on itself and it will not solve any problem by criticizing the social environment. To develop e-commerce, SMEs needs to find a suitable way for its own in the current social economic environment.

For SMEs during the developing process of e-commerce, if there is one obstacle that is not overcome, all the past efforts will turn out to be in vain. Therefore, e-commerce enterprises must clarify what factors must be overcome in the developing process of e-commerce.

What are the hindrance factors of e-commerce for SMEs? How are they related to the success or failure of e-commerce of an enterprise? These questions are the focuses of this article.

\section{THE HINDRANCE FACTORS OF E-COMMERCE DEVELOPMENT}

The Hypothesis of Hindrance Factors of E-commerce Development

For any enterprises to become an e-commerce enterprise, first of all, we should assume it is operating in the current social, political and cultural environment. Since social environment cannot be changed, an enterprise must choose to adapt to it. Therefore, environmental factors are not in the research paradigm of researches on hindrance factors of e-commerce in enterprises.

An enterprise, which wants to become an e-commerce enterprise, should start from its own factor research, divide its factors into several parts, extract the critical factors and build a system of hindrance factors of e-commerce development. Does the division of enterprise factors accord to the process of value creation or to the process of management? Here we only start from the process of value creation.

In an integrated assessment of multiple hindrance factors, we first use the Delphi method (expert scoring method) and Analytic hierarchy process method to filer them out the hindrance factors [7].

By expert scoring and final integration analysis, we can build a model of hindrance factors of e-commerce. The hindrance factors include 12 varieties [8] [9] : the scale and properties of enterprises, leadership, strategy, human resource, technical selection, industry correlation, organization, capital investment, informatization level, e-commerce application level (website factor), customers and supplies. Since customers and suppliers cannot be fully controlled by enterprise itself, these two factors are deleted from the hindrance factors.

We conducted a survey based on the above hindrance factors that influence the e-commerce development of SMEs. 80 questionnaires are distributed. As a result, 63 have returned and 63 are valid.

\section{CORRElation OF HindRANCE FACTORS FOR ENTERPRISES TO DEVELOP THEIR E-COMMERCE}

\section{A. Basic Information}

Most enterprises under investigation are reported to have fewer than 200 people, 12 of them have no more than 20 people, 18 of them have $20-50$ people, 20 have 51-90 people, 11 have 91-120 people, and 2 have $121-200$ people. In the returned surveys, $96 \%$ of the enterprises say they are private or joint-invested. 22 are manufacturers, 21 are IT and software service enterprises, 15 are service and 5 are high-tech.

\section{B. Data Analysis}


TABLE I. GLOSSARY OF THE HINDRANCE FACTORS OF E-COMMERCE

\begin{tabular}{c|c|c|c|c|c|c}
\hline & Mean & Max & Min & Variance & Kurtosis & Skewness \\
\hline \hline $\begin{array}{c}\text { Leadership } \\
\text { Factor }\end{array}$ & 90.00 & 98.00 & 85.00 & 4.733 & 0.586 & 1.070 \\
\hline $\begin{array}{c}\text { Strategy } \\
\text { Factor }\end{array}$ & 68.83 & 96.00 & 9.00 & 32.338 & 2.466 & -1.627 \\
\hline $\begin{array}{c}\text { Human } \\
\text { Resource }\end{array}$ & 55.50 & 87.00 & 7.00 & 37.458 & -1.904 & -0.826 \\
\hline $\begin{array}{c}\text { Technical } \\
\text { Factor }\end{array}$ & 72.50 & 95.00 & 50.00 & 17.120 & -1.481 & 0.050 \\
\hline $\begin{array}{c}\text { Industry } \\
\text { Relevance }\end{array}$ & 63.00 & 90.00 & 10.00 & 30.430 & 1.036 & -1.181 \\
\hline $\begin{array}{c}\text { Organization } \\
\text { Factor }\end{array}$ & 45.50 & 66.00 & 32.00 & 12.486 & 0.348 & 0.826 \\
\hline $\begin{array}{c}\text { Capital } \\
\text { Factor }\end{array}$ & 76.50 & 90.00 & 50.00 & 14.775 & 1.974 & -1.273 \\
\hline $\begin{array}{c}\text { Information } \\
\text { E-commerce }\end{array}$ & 82.00 & 90.00 & 75.00 & 5.404 & -0.613 & 0.250 \\
\hline Other Factors & 22.00 & 59.00 & 0.00 & 20.620 & 2.001 & -1.394 \\
\hline
\end{tabular}

From Table 1, kurtosis and skewness suggests the survey basically fits the normal distribution and is close to the reality. Leadership factor has the largest mean, showing it is the first factor in the e-commerce development. Second, leadership, information and e-commerce have relative small average variance, indicating investigators consistently believe they are the of the survey shows that strategy, human resource and industry correlation differ largely in limiting the e-commerce development of SMEs; also many researchers think there are other factors apart from the above hindrance factors.

\section{Correlation Analysis}

most basic hindrance factors. But the statistical analysis

TABLE II. CORRELATION ANALYSIS OF THE HINDRANCE FACTORS AND E-COMMERCE APPLICATION LEVEL

\begin{tabular}{|c|c|c|c|c|c|c|c|c|c|c|}
\hline & $\begin{array}{l}\text { Leadership } \\
\text { Factor }\end{array}$ & $\begin{array}{l}\text { Strategy } \\
\text { Factor }\end{array}$ & $\begin{array}{c}\text { Human } \\
\text { Resource }\end{array}$ & $\begin{array}{c}\text { Technical } \\
\text { Factor }\end{array}$ & $\begin{array}{c}\text { Industry } \\
\text { Relevance }\end{array}$ & $\begin{array}{l}\text { Organization } \\
\text { Factor }\end{array}$ & $\begin{array}{l}\text { Capital } \\
\text { Factor }\end{array}$ & $\begin{array}{c}\text { Inform } \\
\text {-ation }\end{array}$ & $\begin{array}{l}\text { E-com- } \\
\text { merce }\end{array}$ & $\begin{array}{l}\text { Other } \\
\text { Factors }\end{array}$ \\
\hline $\begin{array}{r}\text { Leadership } \\
\text { Factor }\end{array}$ & 1.000 & & & & & & & & & \\
\hline $\begin{array}{r}\text { Strategy } \\
\text { Factor }\end{array}$ & 0.155 & 1.000 & & & & & & & & \\
\hline $\begin{array}{r}\text { Human } \\
\text { Resource }\end{array}$ & 0.837 & 0.378 & 1.000 & & & & & & & \\
\hline $\begin{array}{r}\text { Technical } \\
\text { Factor }\end{array}$ & 0.647 & 0.441 & 0.868 & 1.000 & & & & & & \\
\hline $\begin{array}{r}\text { Industry } \\
\text { Relevance }\end{array}$ & 0.050 & 0.129 & 0.034 & -0.305 & 1.000 & & & & & \\
\hline $\begin{array}{r}\text { Organization } \\
\text { Factor }\end{array}$ & 0.443 & -0.089 & 0.116 & -0.343 & 0.558 & 1.000 & & & & \\
\hline $\begin{array}{r}\text { Capital } \\
\text { Factor }\end{array}$ & 0.186 & -0.681 & 0.016 & 0.201 & -0.362 & -0.320 & 1.000 & & & \\
\hline Information & -0.016 & -0.146 & -0.212 & -0.460 & -0.148 & 0.587 & -0.436 & 1.000 & & \\
\hline E-commerce & -0.712 & -0.085 & -0.434 & -0.138 & -0.653 & -0.687 & -0.055 & 0.149 & 1.000 & \\
\hline $\begin{array}{r}\text { Other } \\
\text { Factors }\end{array}$ & -0.576 & -0.042 & -0.769 & -0.745 & 0.496 & 0.122 & -0.177 & -0.097 & -0.114 & 1.000 \\
\hline
\end{tabular}

Note: When significance is 0.05 on both sides, the correlation is significant

First, since the hindrance factors of e-commerce are the objective of this study, in the negative value of the correlation analysis, negative value represents the factor is negatively related to the operation of e-commerce, which means it is an obstacle. As to the process of analyzing the above 10 factors, the negative correlation of e-commerce application level and informatization level and e-commerce application level is significant, showing that they indeed hinder the application of e-commerce for enterprises. Other factors, in the combination with the other related factors, create new hindrance factors. Therefore, we should also 
systematically consider other factors apart from the main hindrance factors for e-commerce application. Industry relevance is weakly correlated to leadership and strategy. But industry relevance is significant correlated to technical factors, showing the application of technology differs in different industries and different industries require different technologies.

\section{Survey Analysis}

The survey intentionally designed "Please score the following limiting factors according to their importance".

TABLE III. SUMMARY OF THE RANKING OF HINDRANCE FACTORS

\begin{tabular}{cccccccccc}
\hline $\begin{array}{c}\text { Leadership } \\
\text { Factor }\end{array}$ & $\begin{array}{c}\text { Strategy } \\
\text { Factor }\end{array}$ & Human & Technical & \multicolumn{2}{c}{ Industry } & Organization Capital Informatio & E-com- & Other \\
Fesource & Factor & Relevance & Factor & Factor & n & Factors \\
\hline 1 & 7 & 4 & 5 & 8 & 9 & 6 & 2 & 3 & 10 \\
\hline
\end{tabular}

Leadership is considered the first factor hindering the e-commerce development of SMEs, and the subsequent factors are informatization level, e-commerce application

is not a very significant hindrance factor. level, human resource and technical factor. Organization

\section{E. Regression Analysis}

TABLE IV. SUMMARY OF REGRESSION OF FACTORS

\begin{tabular}{|c|c|c|c|c|c|}
\hline Index & Limiting Factor & $\mathbf{R}^{2}$ & $\begin{array}{c}\text { Standard } \\
\text { Regression } \\
\text { Coefficient }\end{array}$ & F & Sig. \\
\hline 1 & Leadership Factor & 0.786 & 0.612 & 61.271 & .000 \\
\hline 2 & Strategy Factor & 0.642 & 0.678 & 65.223 & .000 \\
\hline 3 & Human Resource & 0.671 & 0.797 & 125.324 & .000 \\
\hline 4 & Technical Factor & 0.783 & 0.745 & 133.459 & .000 \\
\hline 5 & Industry Relevance & 0.462 & 0.635 & 156.771 & .000 \\
\hline 6 & Organization Factor & 0.351 & 0.772 & 134.435 & .000 \\
\hline 7 & Capital Factor & 0.521 & 0.716 & 112.435 & .000 \\
\hline 8 & Information & 0.711 & 0.675 & 321.209 & .000 \\
\hline 9 & E-commerce & 0.681 & 0.735 & 341.089 & .000 \\
\hline 10 & Other factors & 0.342 & 0.364 & 56.704 & .008 \\
\hline
\end{tabular}

From the summary of regression analysis of different factors in Table 4, we can conclude that leadership, information and technology significantly limit the e-commerce development for SMEs. The regression coefficient of leadership and obstacles of the e-commerce development for SMEs is the largest. $\mathrm{R}=0.786$ for leadership, $\mathrm{F}=61.271$ from $\mathrm{F}$ test and the regression coefficient is 0.786 , which means that when leadership solely functions, $78.6 \%$ of obstacles of the e-commerce development for SMEs are from leadership. The coefficient of other factors is the smallest, $\mathrm{R} 2=0.342$, $\mathrm{F}=56.704$ and the regression coefficient is 0.364 , which means that when other factors function alone $34.2 \%$ of variation can be explained.

\section{V.CONCLUSION AND SUGGESTIONS}

Based on the above analysis, in China, the hindrance factors of e-commerce hinder the e-commerce development in SMEs all the time. To successfully develop e-commerce, SMEs must overcome these obstacles.

First, the limiting factors of e-commerce development for SMEs are multi-faceted and cannot be summarized as one or several single factors. The obstacles form a complex "Hindrance factor system". To successfully develop e-commerce in SMEs, SMEs must overcome these obstacles. This is the prerequisite for the success of e-commerce development for SMEs.

Second, different hindrance factors have different resistance power at different stages of the e-commerce development in SMEs, that is, they are sequential. At the early stage, leadership, strategy, capital investment have more resistance power. Therefore, SMEs should emphasize leadership, long-term goal and act according to their ability. As the e-commerce develops, 
e-commerce application level, informatization level, and other factors start to hinder the e-commerce development. Training of employees and reinvestment are then critical.

Finally, human resource and technical factors have great influence upon the e-commerce development process all the time. Although they do not show variance in time, they are the background factors. For the development of e-commerce for SMEs, they must handle these two important background factors well. SMEs must also have enough human resource reserve and edge-cutting technologies. To be a passive follower and be short -sighted will not help achieve a sustainable development.

\section{REFERENCE}

[1] The survey report of Internet application and E-commerce development level in Chinese enterprises in 2009. CNNIC, 2009. http://doc.mbalib.com/view/43b0a8a1fecfd75e6bf6a24eb24f2a05.ht $\mathrm{ml}$.

[2] FENG Ying, XU Zhandong. Empirical Research on Key Factors
Affecting SMEs' Implementation of E-commerce_-Based on the Innovation Diffusion Theory [J]. Soft Science (3):115-120. (2011)

[3] ZHANG Xiaohong, Research on Key Success Factors of E-Commerce in Small and Medium Enterprises in Shanxi[J]. Zhongshan University, (2011)

[4] Deng Ruohong, Wang Wuyi, Yu Chaojiang. Further Research on the Evolutive model of E-commerce Inhibitors [J]. Mathematics in Practice and Theory 2008(23):40-46.

[5] Li Xiuli. The State-quo of E-commerce Application in Chinese SMEs [J]. Guide to Business 2011(13):(2007-2008).

[6] Li Peng. Analysis on the successful factors of E-commerce Application in Chinese SMEs[J] China Business \& Trade, 2011(8):97-98.

[7] Qiu Changbo, Will Foster. Research on the Effect Factors of E-commerce Application in Electronics Industry[J]. Information Science. 2003 , 9(2 1):919 -921.

[8] BAI, Rongru. A Study of Implementation Evaluation and Key Successful Factors on Electronic Commerce[J].Economic Forum. (2009), 8: 124-127.

[9] ZHAO, J. and ZHU, Z. An empirical investigation of critical success factors for e-business strategy implementation [J]. Journal of Tsinghua University (Science and Technology.( 2006), (46) : 914-922. 